NOTE

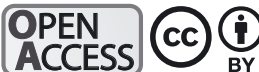

\title{
Experimental analysis of reintroduction strategies to conserve the vulnerable plains topminnow Fundulus sciadicus in Nebraska
}

\author{
David A. Schumann ${ }^{1,5}$, W. Wyatt Hoback ${ }^{1,6}$, Keith D. Koupal ${ }^{2, *}$, \\ Casey W. Schoenebeck ${ }^{1,7}$, Steven C. Schainost ${ }^{3}$, Tammy L. Wilson ${ }^{4}$ \\ ${ }^{1}$ Department of Biology, University of Nebraska at Kearney, $240111^{\text {th }}$ Avenue, Kearney, Nebraska 68849, USA \\ ${ }^{2}$ Nebraska Game and Parks Commission, Kearney Field Office, $16171^{\text {st }}$ Avenue, Kearney, Nebraska 68847, USA \\ ${ }^{3}$ Nebraska Game and Parks Commission, Alliance Field Offices, 299 Husker Road, Alliance, Nebraska 69301, USA \\ ${ }^{4}$ Department of Natural Resource Management, South Dakota State University, Box 2140B, 1390 College Avenue, Brookings, \\ South Dakota 57006, USA \\ ${ }^{5}$ Present address: Department of Wildlife, Fisheries, and Aquaculture, Mississippi State University, Box 9690, \\ Mississippi State, Mississippi 39762, USA \\ ${ }^{6}$ Present address: Entomology and Plant Pathology, Oklahoma State University, 127 Noble Research Center, Stillwater, \\ Oklahoma 74078-3033, USA \\ ${ }^{7}$ Present address: Minnesota Department of Natural Resources, 23070 N Lakeshore Drive, Glenwood, Minnesota 56334, USA
}

\begin{abstract}
Plains topminnow Fundulus sciadicus are endemic to the Great Plains (USA), and because of declines in their geographic range and local abundance, are granted protection throughout their native range. Experimental reintroductions were conducted to improve conservation techniques and enhance the long-term outlook for plains topminnow persistence in Nebraska. Reintroductions were attempted at 17 extirpated stream reaches using low and high founder densities (no. of fish per suitable area) and during 2 seasons (spring and fall) to identify successful techniques for future conservation efforts. Reintroduced populations were sampled monthly (excluding winter) for $2 \mathrm{yr}$ to monitor population persistence. Repeated presenceabsence data was used to estimate persistence probabilities (1 - extinction probability), which we used to compare reintroduction strategy treatments. Plains topminnow were recaptured at $76 \%$ of reintroduction locations (1456 total individuals) and reproduction was observed at $35 \%$ of those sites. Catch rates at reintroduction sites varied substantially (range: 0 to 30.78 ind. per $100 \mathrm{~m}$ ). The influence of season and founder density were minimal. Population persistence was more likely at sites stocked in fall at higher densities; however, wide confidence intervals suggest that individual site characteristics may more strongly influence population persistence. Similar population outcomes regardless of reintroduction strategy provide managers flexibility when making conservation decisions.
\end{abstract}

KEY WORDS: Reintroduction $\cdot$ Plains topminnow $\cdot$ Strategy $\cdot$ Season $\cdot$ Founder density

\section{INTRODUCTION}

Native fish communities throughout North America have been changed because of habitat loss, introduced nonnative species, and agricultural develop-

${ }^{*}$ Corresponding author: keith.koupal@nebraska.gov ment (Rahel 2002, Burkhead 2012). Anthropogenic impacts may result in continued declines in both the distribution and local abundance of sensitive fish species, at times resulting in local extinction events (Rahel 2002, Fischer \& Paukert 2008). Recovering 
populations in historically occupied habitats is a fundamental conservation strategy to manage genetic diversity and restore ecosystem services (Griffith et al. 1989, Sarrazin \& Barbault 1996, Reading et al. 2002, Marsh et al. 2005). Captive propagation and reintroduction programs can reduce the risk of species loss by reestablishing locally extirpated populations and/or augmenting at-risk populations (Seddon et al. 2007, George et al. 2009, Kline \& Bonar 2009, Schumann et al. 2012).

Numerous reintroduction programs have attempted to restore rare fishes, but little is known about why these efforts have overwhelmingly failed to meet biological goals (Marsh et al. 2005, Seddon et al. 2007, George et al. 2009). The vast majority of fish reintroduction attempts are poorly documented (Fischer \& Lindenmayer 2000, George et al. 2009), and projects have rarely been designed to evaluate reasons for success or failure (Seddon et al. 2007). Thus, much of the existing literature has retrospectively evaluated reintroduction success and provides little guidance for future attempts (Seddon et al. 2007).

Plains topminnow Fundulus sciadicus populations have declined throughout the Great Plains and are granted protection throughout their native range (Pasbrig et al. 2012). The species was not observed at more than $65 \%$ of 427 historical Nebraska sites, the state with the widest distribution (Pasbrig et al. 2012). Extensive agricultural development, dewatering and channelization of lotic habitats, and the establishment of nonnative predatory fishes have potentially impacted plains topminnow populations (Fischer \& Paukert 2008, Schumann et al. 2015a, 2016). Concerns over the species' decline have warranted its consideration for federal protection and prompted directed management action in Nebraska.

Attempts to reintroduce the species to historically occupied stream reaches were determined necessary to restore populations in Nebraska (M. Fritz NGPC, pers. comm.). Plains topminnow are a good candidate species for reintroduction efforts; individuals mature early in life and, in suitable habitats, the species is capable of rapid population growth (Kinney \& Lynch 1991, Schumann et al. 2012). The goal of this study was to experimentally evaluate reintroduction efforts to refine strategies and enhance the multi-generation survival of future reintroduced populations of plains topminnow in Nebraska. Our objective was to determine if initial population density and/or season of reintroduction affected the persistence of released populations.

\section{MATERIALS AND METHODS}

\section{Study area}

We selected 17 reintroduction sites in Nebraska, each occurring within the known historic range of plains topminnow, and where the species has been historically captured but was missing in recent surveys (see Fig. 1). We restricted reintroduction efforts to sites within the Loup, Elkhorn, and Platte River drainages to avoid potential population consequences of introducing genetically dissimilar individuals ( $\mathrm{Li}$ et al. 2009, Byrne \& Pitchford 2016). These 3 drainages are known to contain a genetically indistinguishable plains topminnow clade (Bessert 2011). Prior to reintroduction efforts, we sampled the local fish assemblage using 3-pass depletion backpack electrofishing with block-nets. This assessment, paired with recent range-wide sampling efforts (see Pasbrig et al. 2012), confirmed that plains topminnow were not present at reintroduction sites.

\section{Plains topminnow reintroductions}

Plains topminnow were reared at the Rock Creek State Fish Hatchery, Nebraska. This captive population originated from a wild stock from Dry Creek, near Calamus, Nebraska in the Loup River drainage. All topminnows were measured to total length (TL; $\mathrm{mm}$ ) prior to transportation. Fish were transported to reintroduction sites and acclimated to local water temperatures with water exchanges prior to release.

\section{Reintroduction strategies}

Fish were reintroduced during 2 seasons: spring and fall (Table 1). Each site was randomly assigned a reintroduction season, resulting in 11 sites with individuals stocked in October and 6 sites stocked in March. In general, adult ( $\geq$ age-1) plains topminnow were released in spring and juvenile (age-0) individuals were reintroduced in fall. Individuals stocked in spring ( $\mathrm{TL} \pm \mathrm{SE}: 47.3 \pm 0.53 \mathrm{~mm}$ ) were generally larger (unpaired $t$-test: $t=-20.3, \mathrm{df}=398, \mathrm{p}<0.001$ ) than those stocked in fall $(36.1 \pm 0.16 \mathrm{~mm})$.

Reintroduced founder densities were calculated using the total amount of slackwater habitat available to the species at each site (Table 1). Available habitat for plains topminnow was estimated using the velocity tolerances of similar species: $0.385 \mathrm{~m}^{-1}$ for western mosquitofish Gambusia affinis and 
Table 1. Randomly assigned reintroduction founder population density and seasons with catch rates of plains topminnow at each of 17 selected historic sites in Nebraska based upon the amount of habitat available to the species. High introduction rates were 2500 fish per habitat acre $\left(6178 \mathrm{fish} \mathrm{ha}^{-1}\right)$ and low introduction rates were 1000 fish habitat acre $\left(2471 \mathrm{fish}\right.$ ha $\left.{ }^{-1}\right)$

\begin{tabular}{|c|c|c|c|c|c|c|c|}
\hline Site & $\begin{array}{c}\text { Founder } \\
\text { density }\end{array}$ & $\begin{array}{l}\text { Stocking } \\
\text { season }\end{array}$ & $\begin{array}{c}\text { Suitable } \\
\text { habitat (ha) }\end{array}$ & $\begin{array}{l}\text { Number } \\
\text { released }\end{array}$ & Recaptures & $\begin{array}{c}\text { Mean }( \pm \mathrm{SE}) \\
\text { catch per } 100 \mathrm{~m}\end{array}$ & $\begin{array}{c}\text { Reproduction } \\
\text { observed }\end{array}$ \\
\hline North Platte River & Low & Fall & 0.219 & 540 & 12 & $0.3 \pm 0.09$ & \\
\hline Cache Creek & Low & Fall & 0.106 & 263 & 0 & 0 & \\
\hline Dismal River & Low & Fall & 0.491 & 1213 & 344 & $8.2 \pm 1.99$ & $\mathrm{X}$ \\
\hline Middle Loup River & Low & Fall & 0.339 & 838 & 11 & $0.2 \pm 0.10$ & \\
\hline Cedar River & Low & Fall & 0.056 & 138 & 17 & $0.3 \pm 0.19$ & $\mathrm{X}$ \\
\hline South Branch Turtle Creek & Low & Spring & 0.020 & 49 & 3 & $0.1 \pm 0.10$ & \\
\hline Middle Loup River & High & Spring & 0.035 & 216 & 103 & $2.6 \pm 0.45$ & $\mathrm{X}$ \\
\hline South Loup River & High & Spring & 0.125 & 770 & 7 & $0.2 \pm 0.08$ & \\
\hline Cedar River & High & Spring & 0.063 & 387 & 29 & $0.6 \pm 0.35$ & $\mathrm{X}$ \\
\hline Mud Creek & High & Spring & 0.038 & 235 & 0 & 0 & \\
\hline Sweet Creek & High & Spring & 0.107 & 662 & 36 & $1.4 \pm 0.55$ & \\
\hline Lodgepole Creek & High & Fall & 0.034 & 209 & 0 & 0 & \\
\hline Winters Creek & High & Fall & 0.013 & 79 & 0 & 0 & \\
\hline Lodgepole Creek & High & Fall & 0.066 & 406 & 785 & $30.8 \pm 5.93$ & $\mathrm{X}$ \\
\hline Clear Creek & High & Fall & 0.028 & 171 & 21 & $1.0 \pm 0.54$ & $\mathrm{X}$ \\
\hline Dismal River & High & Fall & 0.029 & 181 & 53 & $1.0 \pm 0.21$ & \\
\hline Platte River & High & Fall & 0.054 & 335 & 35 & $1.1 \pm 0.47$ & \\
\hline
\end{tabular}

$0.365 \mathrm{~m}^{-1}$ for Gila topminnow Poeciliopsis occidentalis (Ward et al. 2003). Areas, at baseflow, with mean velocities $<0.36 \mathrm{~m}^{-1}$ were considered available to plains topminnow. The total area (ha) available was used to determine the number of individuals released (Table 1). The amount of suitable habitat at each reintroduction site varied (mean \pm SE: $0.107 \pm 0.031$ ha; range: 0.013 to $0.491 \mathrm{ha}$ ). No information was available about the appropriate number of plains topminnow to stock, so founder population densities were based on published values for western mosquitofish (Duryea et al. 1996). We used both a high stocking rate $(2500$ fish per available habitat acre, or 6178 fish $\mathrm{ha}^{-1}$ ) and a low stocking rate (1000 fish per habitat acre; 2471 fish ha $^{-1}$ ) (Duryea et al. 1996). Between 49 and 1213 individuals were released at each reintroduction site (mean \pm SE: $394 \pm 77$ ). Initial founder population sizes were randomly assigned to each site resulting in 11 sites stocked at the high rate and 6 sites stocked at the low level (Table 1).

\section{Population monitoring}

We defined a sampling reach (i.e. reintroduction site) as 40 times the mean stream width (range: 150 to $300 \mathrm{~m}$ ), based on measurements at 5 random points (Patton et al. 2000). No sampling was conducted outside of the reintroduction site; however, dispersal of plains topminnow away from reintroduction sites has been previously described (Schumann et al. 2015b).
After the initial reintroductions, sites were sampled monthly, excluding December to February, using single-pass electrofishing. Backpack electrofishing started at the downstream endpoint of the sampling reach and moved upstream. All reintroduction sites were first sampled the month following fish releases. Reintroduction sites first stocked in October 2010 were sampled from November 2010 through September 2012, and sites where individuals were released in March 2011 were sampled between April 2011 and October 2012. Catch rates (number per $100 \mathrm{~m}$ ) were calculated from each sampling event. Reproduction of plains topminnow was assumed if individuals $<25 \mathrm{~mm}$ TL were encountered (Rahel \& Thel 2004, Schumann et al. 2012).

\section{Evaluating reintroduction strategies}

We estimated the persistence probability of each reintroduced population as the inverse of extinction probability $(1$ - extinction probability) using replicated presence-absence recapture data (PRESENCE Software; MacKenzie \& Royle 2005). This analysis allowed us to estimate the likelihood that the reintroduced populations would persist, and test the effects of each reintroduction strategy covariate. Multiseason robust-design occupancy models were developed using our monthly samples as replicate surveys within 3 seasons (spring: March, April, and May; summer: June, July, and August; fall: September, 
October, and November) over a 2 yr period. In these models, colonization and detection were allowed to vary by season, mirroring behaviors and sampling efficiencies previously described (Schumann et al. 2015a). Occupancy was held constant. The influence of each reintroduction strategy was assessed by parameterizing models that included and excluded their effect on topminnow persistence. Models were ranked by corrected Akaike's information criterion $\left(\Delta \mathrm{AIC}_{\mathrm{c}}\right)$ values and individual model performance was assessed using the likelihood-ratio test (LRT) (Burnham \& Anderson 2002). The relative influence of each predictor was described 2 ways: (1) by calculating the odds-ratio for each strategy covariate from its estimated coefficient, and (2) summing the weights of models that include each covariate (MacKensie et al. 2006).

\section{RESULTS}

No plains topminnow were captured at release sites prior to reintroduction efforts. In total, 13384 individual plains topminnow were released to evaluate the 2 reintroduction strategies (Table 1). During our 2 yr post-reintroduction monitoring program, we captured 1456 plains topminnow (Table 1). Plains topminnow were recaptured at $76 \%$ of reintroduction sites and reproduction was observed at $35 \%$ of those sites (Table 1). However, rarely were many young individuals captured at a single reintroduction site. Successful plains topminnow population establishment, as defined by Nebraska managers (persistence probability $>0.5$ ), was achieved at $41 \%$ of reintroduction sites (Fig. 1). Mean $( \pm \mathrm{SE})$ catch of plains topminnow per $100 \mathrm{~m}$ was $2.8 \pm 1.76$, but ranged

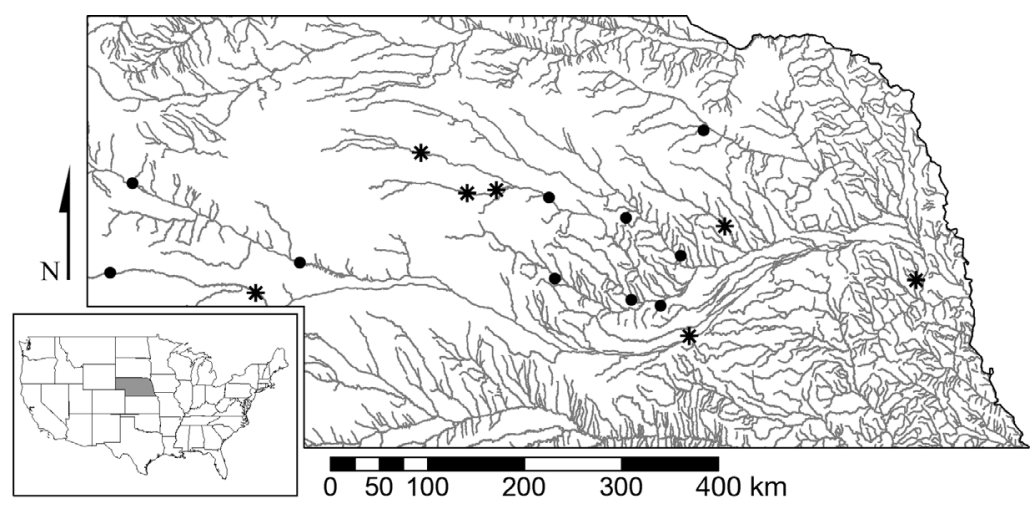

Fig. 1. Distribution of the 17 historically occupied sites in which plains topminnow reintroduction efforts were conducted in Nebraska, USA. Successful establishment, by Nebraska management standards (persistence probability $>0.5$ ), was achieved at sites marked with an asterisk $\left({ }^{*}\right)$
Table 2. Mean $( \pm \mathrm{SE})$ catch per $100 \mathrm{~m}$ and persistence probability of plains topminnow populations released at 17 reintroduction sites in Nebraska during different seasons and at low and high founder densities

\begin{tabular}{|lcc|}
\hline Reintroduction strategy & $\begin{array}{r}\text { Catch rate (no. } \\
\text { of fish per 100 m) }\end{array}$ & $\begin{array}{l}\text { Persistence } \\
\text { probability }\end{array}$ \\
\hline Season & & \\
Spring & $0.82 \pm 0.41$ & $0.34 \pm 0.13$ \\
Fall & $3.90 \pm 2.78$ & $0.43 \pm 0.10$ \\
Founder density (fish ha & \\
Low $\left(2471 \mathrm{ha}^{-1}\right)$ & & \\
High $\left(6178 \mathrm{ha}^{-1}\right)$ & $1.52 \pm 1.33$ & $0.36 \pm 0.13$ \\
& $3.52 \pm 2.74$ & $0.42 \pm 0.11$ \\
\hline
\end{tabular}

from 0 , at 4 different sites, to $30.78 \pm 5.93$ (Table 1). Catch rates did not differ significantly between experimental reintroduction seasons or founder densities (Table 2).

\section{Evaluation of reintroduction strategies}

Mean persistence probability was relatively high regardless of reintroduction strategy; however, broad variance revealed differential responses by site (Table 2). Negligible separation among $\mathrm{AIC}_{\mathrm{c}}$ values suggests that the experimental treatments had little influence on the expected persistence of reintroduced populations (Table 3). No additional support was provided for the candidate models that included the influence of reintroduction season (LRT $=0.6$, $\mathrm{df}=1, \mathrm{p}>0.05$ ) or founder population density (LRT $=$ $3.3, \mathrm{df}=1, \mathrm{p}>0.05$ ) when compared to the null model (Table 3 ). The additive (founder population density + reintroduction season) model did not fit the data significantly better than the null model (LRT $=4.6, \mathrm{df}=$ $2, \mathrm{p}>0.05)$. The candidate model that used the actual number of fish released rather than founder density to predict persistence was not well supported and performed significantly worse than the null model (LRT = 6.9, df = 1, p < 0.05).

Although treatment coefficients estimate continued population persistence to be 1.7 times more likely (95\% CI: 0.26, 11.68) for reintroductions conducted in fall, there was minimal support for the model (summed model weight $=0.24$ ). Founder population density had a potentially stronger influence on persistence probability (summed model weight = 0.49). Population persistence was 6.6 times greater (95\% CI: 0.28, 162.42) at sites 
Table 3. Multi-season robust-design occupancy candidate models with associated number of estimable parameters $(k)$, corrected Akaike's information criterion $\left(\Delta \mathrm{AIC}_{\mathrm{c}}\right)$ and model weight values, and maximum likelihood estimates used to evaluate plains topminnow reintroduction strategies developed using 3 monthly samples as replicate surveys within 3 seasons over a 2 yr period. The influence of each stocking strategy was assessed by parameterizing models that both included and excluded their effect on persistence probability (1 - extinction probability)

\begin{tabular}{|lcccc|}
\hline Model & $k$ & $\Delta \mathrm{AIC}_{\mathrm{c}}$ & $\begin{array}{c}\text { Model } \\
\text { weight }\end{array}$ & $\begin{array}{c}\text { Max. likelihood } \\
\text { estimate }\end{array}$ \\
\hline Null model & 20 & 0.00 & 0.39 & 256.66 \\
$\begin{array}{l}\text { Founder density } \\
\text { Stocking season }+\end{array}$ & 21 & 0.34 & 0.33 & 255.00 \\
$\quad$ founder density & 1.68 & 0.16 & 254.34 \\
$\begin{array}{l}\text { Stocking season } \\
\text { Number released }\end{array}$ & 21 & 3.14 & 0.08 & 257.80 \\
\hline
\end{tabular}

stocked at the high density. Wide confidence intervals for both odds-ratio estimates suggest that other factors or individual site characteristics have a greater impact on plains topminnow persistence than reintroduction strategy.

\section{DISCUSSION}

Reestablishment of extirpated populations with reintroductions to known historical locations is likely to become an increasingly important conservation tool to recover imperiled fish (Marsh et al. 2005). Despite the importance of this conservation tool, few fish reintroduction programs have thoroughly examined success rates for different reintroduction strategies (Seddon et al. 2007, George et al. 2009). Descriptions of reintroduction techniques have most often been limited to retrospective accounts that have generally been unable to improve future conservation efforts (Minckley 1995, Seddon et al. 2007). We initiated a successful reintroduction program for plains topminnow that expanded the current distribution of this rare species in Nebraska. Our experimental treatments and monitoring program provide clear support for future plains topminnow reintroductions by documenting the persistence of adult individuals and reproduction at streams stocked using diverse strategies (MacKenzie \& Royle 2005, George et al. 2009). Although the underlying issues that caused extirpation have not been resolved, we provide a means to maintain populations of this rare fish at historically known sites until other restoration activities are devised.
Neither reintroduction season nor founder population density influenced population persistence. Although population persistence was more likely at sites stocked at higher densities and, to a lesser extent, in fall, wide confidence intervals suggest that individual site characteristics may have a greater impact on population persistence. Managers can expect plains topminnow populations to persist at similar rates whether released in fall or spring. However, the time of year when reintroductions occur may influence future reproduction and recruitment (e.g. Gila topminnow; Sheller et al. 2006). We observed reproduction within $2 \mathrm{yr}$ at sites stocked in both seasons. Managers may prefer to reintroduce plains topminnow in fall as this would preclude the need to overwinter broodstock and would not hinder future reproduction.

The motivation for all reintroduction efforts is to restore populations with sufficient individuals to maintain genetic diversity and ensure reproductive capabilities (Minckley 1995, Sarrazin \& Barbault 1996, George et al. 2009). Most reintroduction programs recommend releasing several hundred individuals; however, variability of life history traits, habitat quality, or population structures make these numbers capricious (Minckley 1995, Sarrazin \& Barbault 1996). Although stocking at the higher density was seemingly beneficial, other variables not included in the analysis were more influential, as the models that included stocking density received no more support than the null model. By recognizing similar population outcomes regardless of reintroduction strategy, we provide flexibility for managers with respect to future conservation decisions when the option to restore suitable habitats is unavailable.

In our study, populations persisted at sites stocked with few individuals $(\mathrm{n}=138)$, and only 123 individuals were needed to establish a broodstock population in a piscivore-free environment (Schumann et al. 2012). If a minimum threshold exists for successful plains topminnow reintroductions, we suspect that it is $\sim 125$ individuals. Future reintroduction programs could allocate resources to a greater number of sites rather striving to releasing high densities of fish at each site. Managers are generally wary of introducing a small number of individuals for numerous reasons, including genetic concerns (George et al. 2009). Genetic diversity among plains topminnow populations is 'strikingly low' compared to other topminnow species as a result of past population expansions and bottlenecks (Bessert 2011). Thus, relatively few plains topminnow can establish persistent populations without sacrificing genetic integrity (Bessert 2011). 
Like other opportunistic species, plains topminnow have life history traits that facilitate widespread dispersal, and their populations can increase rapidly in suitable habitats (Kinney \& Lynch 1991, Winemiller \& Rose 1992, Schumann et al. 2012, 2015b). In just 2 yr, we were able to demonstrate that reproduction had occurred at $35 \%$ of reintroduction sites. Plains topminnow have relatively short lifespans $(<4 \mathrm{yr}$; Stribley \& Stasiak 1982) and after the reproductive season, age-0 individuals can represent as much as $95 \%$ of the population (Rahel \& Thel 2004). Because older individuals are thought to be rare $(\sim 4 \%$ of populations) and growth of age-0 individuals is fast, we potentially underestimated reproduction at sites in which populations persisted (Rahel \& Thel 2004). The persistence of plains topminnow at reintroduction sites through multiple generations despite high mortality rates suggests that reproduction has widely occurred. At sites where plains topminnow did not persist, it is possible that critical habitat for this species is no longer available; however, mobile individuals may seek and occupy suitable habitat elsewhere (Schumann et al. 2015b).

Reintroductions may enhance and prolong population persistence of plains topminnow but they do not alleviate factors that caused the original extirpation. Obstacles to species recovery in streams will continue to increase, as constant threats of habitat degradation and nonnative species introductions coincide with large-scale impacts of climate change (Cooke et al. 2012). Of particular concern, the invasive western mosquitofish has become widespread in Nebraska and occupies a similar niche as plains topminnow (Schumann et al. 2015a). This species has been reported to compete with and prey upon closely related species including plains topminnow (Schumann et al. 2015a), and has resulted in local extirpation of other small fishes (Laha \& Mattingly 2007, Robinson \& Ward 2011). Reintroductions to areas with potential competitors of similar size and ecological role are often less successful than reintroductions to areas without competitors (Griffith et al. 1989, Goldsworthy \& Bettoli 2006). New research is evaluating the influence of local instream habitat and fish assemblage structure on the long-term persistence of reintroduced plains topminnow populations (J. Thiessen et al. unpubl. data).

The list of information that needs to be obtained to effectively manage plains topminnow is still long. Despite the unlikely resolution of the original sources of population decline and new challenges with invasive species, we have described suitable methods to maintain this species at historically occupied sites.
The development of a broadly applicable paradigm for the reintroduction of rare fishes promises to improve long-term persistence rates but requires similar analyses of reintroduction technique methods, results, and strategies (Griffith et al. 1989, Reading et al. 2002).

Acknowledgements. The authors thank the Nebraska Game and Parks Commission Fisheries Division, University of Nebraska at Kearney Biology Department, and the Nebraska State Wildlife Grant Program (T2F8R001 and T2F8R002) for project funding support. Special thanks are offered to the staff at the Rock Creek State Fish Hatchery, Nebraska, for providing technical advice and project support with marking and housing fish, monitoring tanks and water flow, and housing equipment. Individuals from these hatcheries include: Gerald Coates, Hal Walker, and Clayton Funk. Assistance with marking, population monitoring, and technical support was provided by Chelsey Pasbrig, Chris Uphoff, Jacob Wirtz, Mike Cavallaro, Seth Lundgren, John Howard, Zachariah Woiak, Rebecca Pawlak, Josh Krietman, Zach Lind, Erik Prenosil, Jeremy Grauf, and Joe Thiessen. Mention of product or trade names does not imply endorsement by the US Government for any product or service.

\section{LITERATURE CITED}

Bessert ML (2011) Conservation genetics of the plains topminnow (Fundulus sciadicus) in Nebraska - prioritizing populations for future conservation. Final Report to the Nebraska Game and Parks Commission, State Wildlife Grant T-71-R. Nebraska Game and Parks Commission, Lincoln, NE

Burkhead NM (2012) Extinction rates in North American freshwater fishes, 1900-2010. Bioscience 62:798-808

Burnham KP, Anderson DR (2002) Model selection and multimodel inference: a practical information-theoretic approach. Springer-Verlag, New York, NY

Byrne JGD, Pitchford JW (2016) Species reintroduction and community-level consequences in dynamically simulated ecosystems. Biosci Horiz 9:hzw009

Cooke SJ, Paukert C, Hogan Z (2012) Endangered river fish: factors hindering conservation and restoration. Endang Species Res 17:179-191

Duryea R, Donnelly J, Guthrie D, O'Malley C, Romanowski M, Schmidt R (1996) Gambusia affinis effectiveness in New Jersey mosquito control. In: Proc $83^{\text {rd }}$ NJ Mosquito Control Association, 1996, p 95-102

Fischer J, Lindenmayer DB (2000) An assessment of the published results of animal relocations. Biol Conserv 96: $1-11$

Fischer JR, Paukert CP (2008) Historical and current environmental influences on an endemic Great Plains fish. Am Midl Nat 159:364-377

George AL, Kuhajda BR, Williams JD, Cantrell MA, Rakes PL, Shute JR (2009) Guidelines for propagation and translocation for freshwater fish conservation. Fisheries (Bethesda, MD) 34:529-545

*Goldsworthy CA, Bettoli PW (2006) Growth, body condition, reproduction and survival of stocked Barrens topminnow, Fundulus julisia (Fundulidae). Am Midl Nat 156: 331-343 
Griffith B, Scott JM, Carpenter JW, Reed C (1989) Translocation as a species conservation tool: status and strategy. Science 245:477-480

Kinney TA, Lynch JD (1991) The fecundity and reproductive season of Fundulus sciadicus in Nebraska (Actinopterygii: Fundulidae). Trans Nebr Acad Sci 18: 101-104

Kline SJ, Bonar SA (2009) Captive breeding of endangered Yaqui topminnow and Yaqui chub for recovery purposes. N Am J Aquacult 71:73-78

Laha M, Mattingly HT (2007) Ex situ evaluation of impacts of invasive mosquitofish on the imperiled Barrens topminnow. Environ Biol Fishes 78:1-11

* Li C, Bessert ML, Macrander J, Ortí G (2009) Low variation but strong population structure in mitochondrial control region of the plains topminnow, Fundulus sciadicus. J Fish Biol 74:1037-1048

MacKenzie DI, Royle JA (2005) Designing occupancy studies: general advice and allocating survey effort. J Appl Ecol 42:1105-1114

MacKenzie DI, Nichols JD, Royle JA, Pollock KH, Bailey LL, Hines JE (2006) Occupancy estimation and modeling. Academic Press, Burlington, MA

Marsh PC, Kesner BR, Pacey CA (2005) Repatriation as a management strategy to conserve a critically imperiled fish species. N Am J Fish Manage 25:547-556

Minckley WL (1995) Translocation as a tool for conserving imperiled fishes: experiences in western United States. Biol Conserv 72:297-309

Pasbrig CA, Koupal KD, Schainost S, Hoback WW (2012) Changes in range-wide distribution of plains topminnow Fundulus sciadicus. Endang Species Res 16:235-247

Patton TM, Rahel FJ, Gerow KG (2000) Effort needed to estimate species richness in small streams on the Great Plains in Wyoming. N Am J Fish Manage 20:394-398

Rahel RJ (2002) Homogenization of freshwater faunas. Annu Rev Ecol Syst 33:291-315

Rahel FJ, Thel LA (2004) Plains topminnow (Fundulus sciadicus): a technical conservation assessment. USDA Forest Service, Rocky Mountain Region, Lakewood, $\mathrm{CO}$

Reading RP, Clark TW, Kellert SR (2002) Towards an endan-

Editorial responsibility: Eduardo Martins,

Vancouver, British Columbia, Canada gered species reintroduction paradigm. Endang Species Update 19:142-146

Robinson AT, Ward DL (2011) Interactions between desert pupfish and Gila topminnow can affect reintroduction success. N Am J Fish Manage 31:1093-1099

Sarrazin F, Barbault R (1996) Reintroduction: challenges and lessons for basic ecology. Trends Ecol Evol 11:474-478

Schumann DA, Pasbrig CA, Koupal KD, Hoback WW (2012) Culture of plains topminnow, Fundulus sciadicus, in a pond constructed for species conservation. N Am J Aquacult 74:360-364

Schumann DA, Hoback WW, Koupal KD (2015a) Complex interactions between native and invasive species: investigating the differential displacement of two topminnows native to Nebraska. Aquat Invasions 10:339-346

Schumann DA, Koupal KD, Hoback WW, Schoenebeck CW, Schainost S (2015b) Large-scale dispersal patterns and habitat use of plains topminnow Fundulus sciadicus: implications for species conservation. J Freshwat Ecol 30: 311-322

Schumann DA, Koupal KD, Schoenebeck CW, Hoback WW (2016) Fish assemblage structure and single-species occurrence: valuable insight into interspecific interactions of a poorly understood species. Am Midl Nat 176: 186-199

Seddon PJ, Armstrong DP, Maloney RF (2007) Developing the science of reintroduction biology. Conserv Biol 21: 303-312

Sheller FJ, Fagan WF, Unmack PJ (2006) Using survival analysis to study translocation success in the Gila topminnow (Poeciliopsis occidentalis). Ecol Appl 16:1771-1784

Stribley JA, Stasiak RH (1982) Age, growth and food habits of the plains topminnow, Fundulus sciadicus Cope, in Keith County, Nebraska. Trans Nebr Acad Sci Affil Soc 92:17-18

WWard DL, Schultz AA, Matson PG (2003) Differences in swimming ability and behavior in response to high water velocities among native and nonnative fishes. Environ Biol Fishes 68:87-92

Winemiller KO, Rose KA (1992) Patterns of life-history diversification in North American fishes: implications for population regulation. Su Ürün Derg 49:2196-2218

Submitted: June 7, 2017; Accepted: September 14, 2017 Proofs received from author(s): October 31, 2017 